
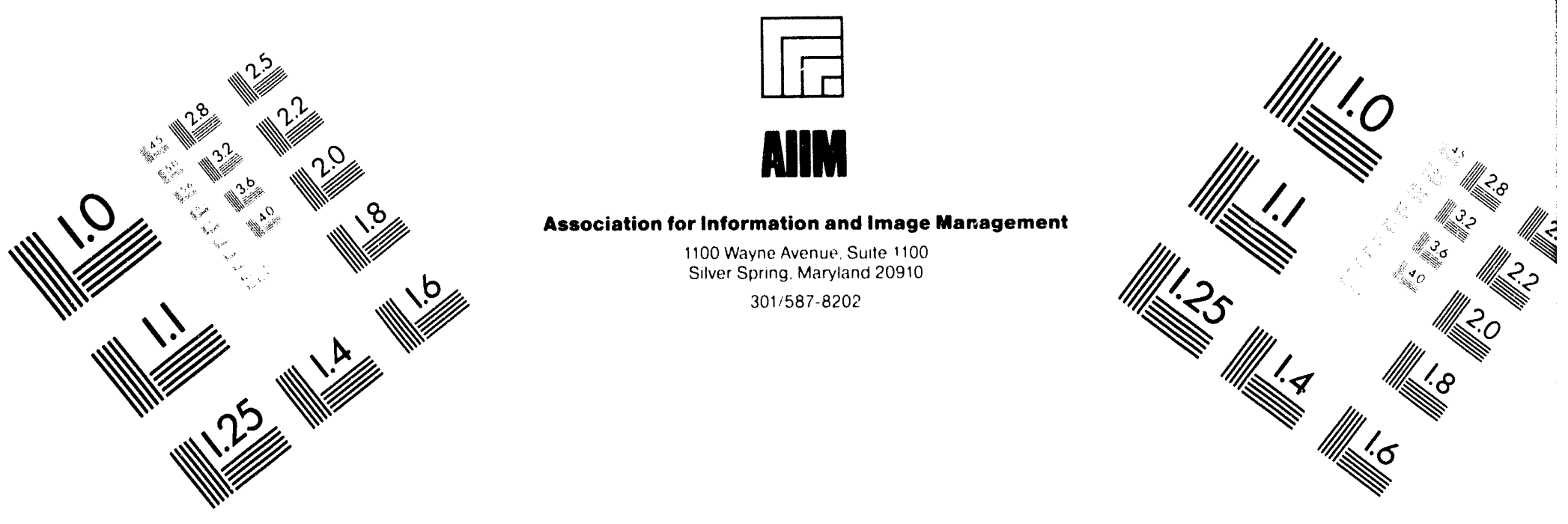

\title{
Centimeter
}

| Inches
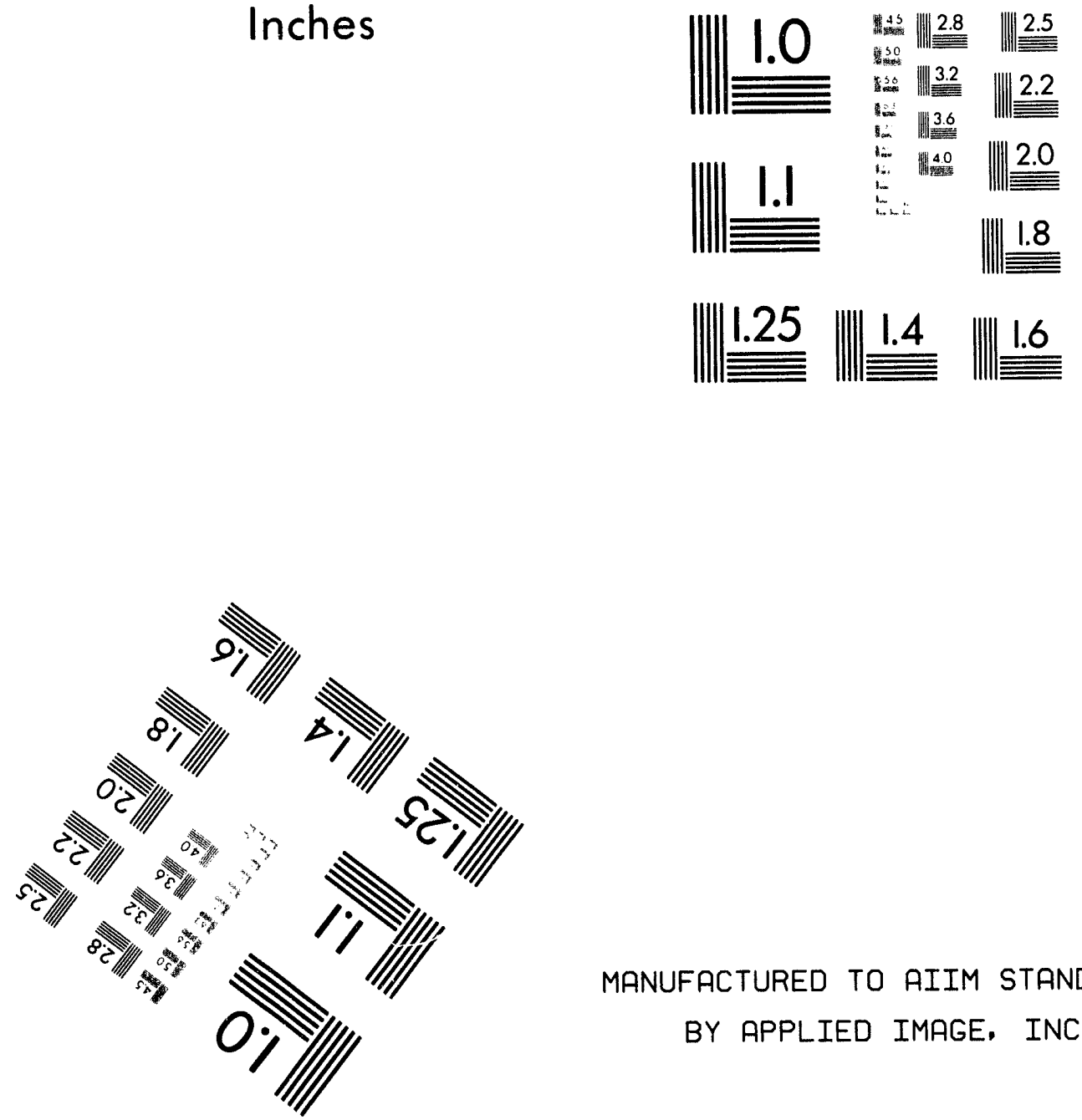

MANUFACTURED TO AIIM STANDARDS

BY APPLIED IMAGE. INC.

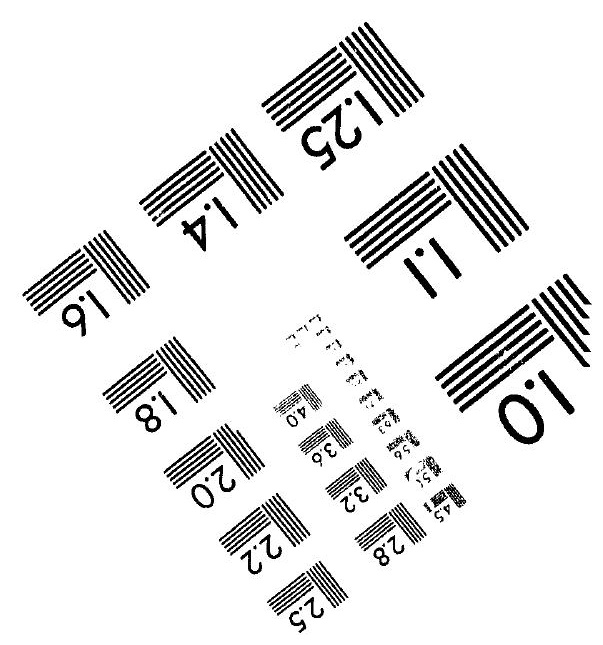



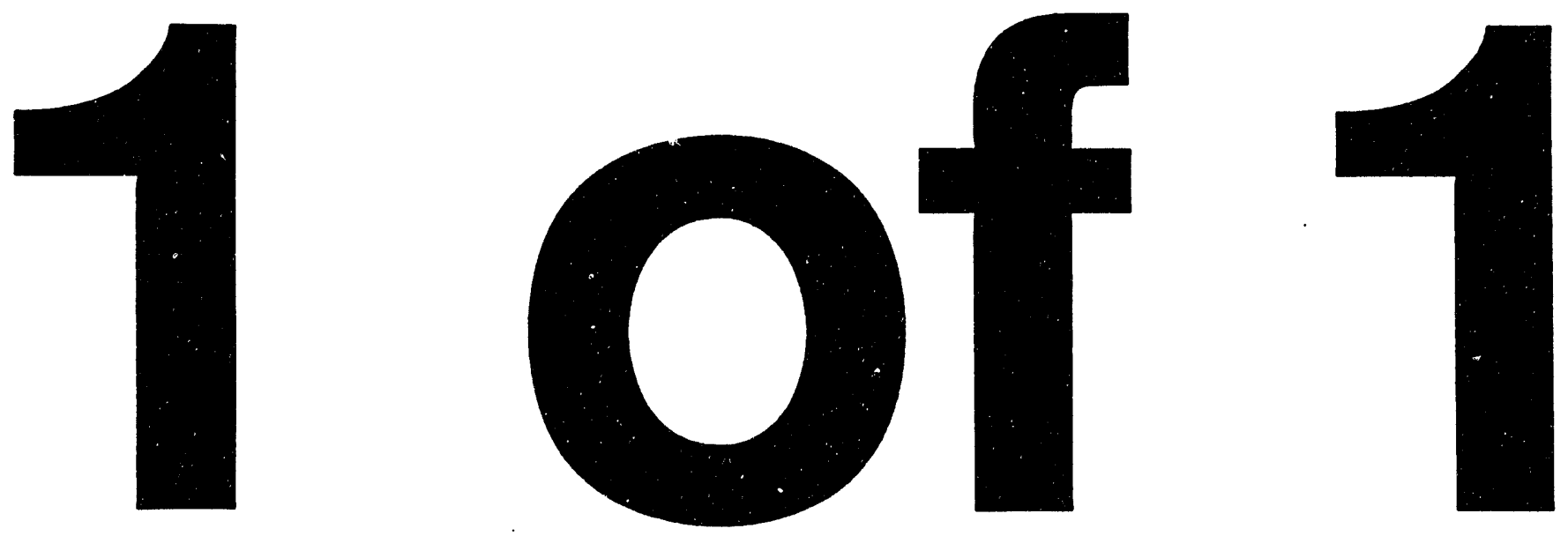


\section{Superplasticity and Superplastic Forming of Ceramics}

T.G. Nieh

J. Wadsworth

May 1994

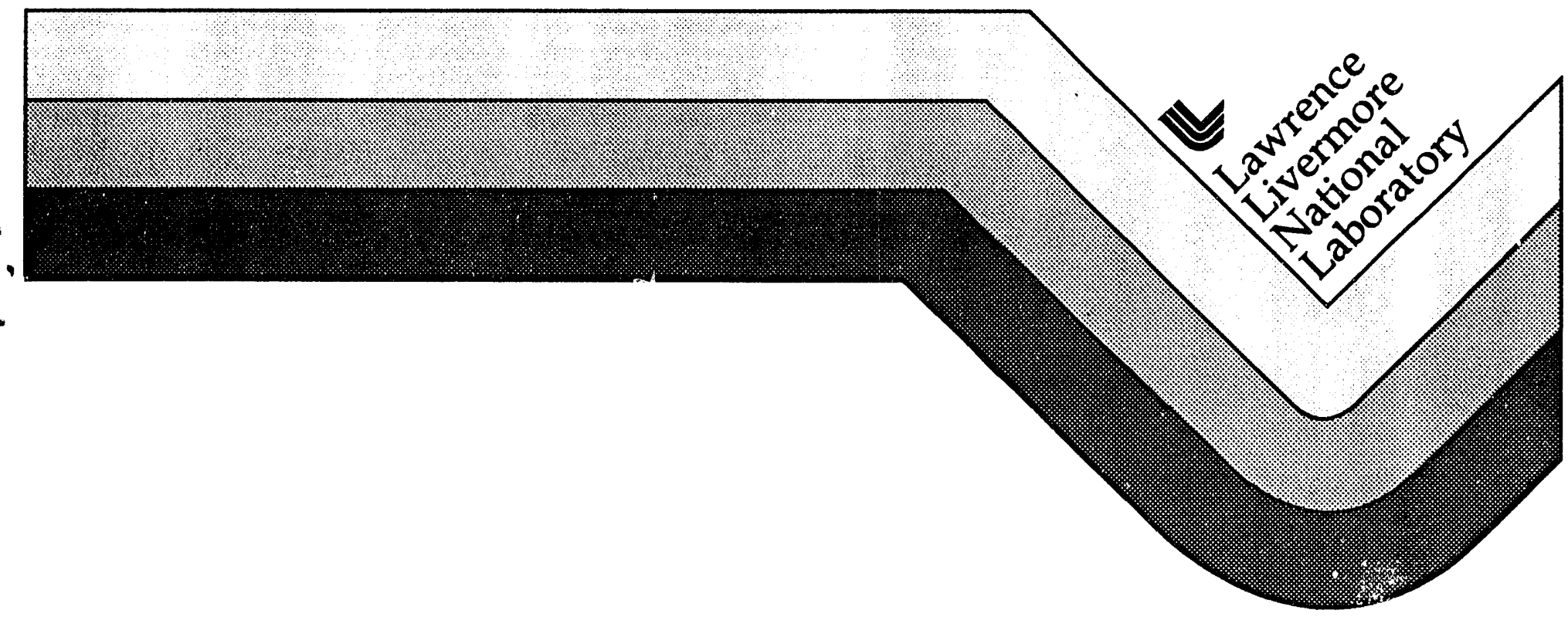




\section{DISCLAIMIER}

Work performed under the auspices of the U.S. Department of Energy by Lawrence Livermore National Laboratory under contract number W-7405-ENG-48.

This document was prepared as an account of work sponsored by an agency of the Inited States Government. Neither the United States Government nor the University of California nor any of their employees, makes any warranty, express or implied, or assumes any legal liability or responsibility for the accuracy, completeness, or usefulness of any information, apparatus, product, or process disclosed, or represents that its use wuuld not infringe privately on ned rights. Reference herein to any specific commercial products, process, or service by trade name, trademark, manufacturer, or otherwise, does not necessarily constitute or imply its endorsement, recommendation. or favoring by the L'nited States Government or the Lniversity of California. The views and opinions of authors expressed herein do not necessarily state or reflect those of the L nited States Government or the University of California, and shall not be used for advertising or product endorsement purposes. 


\title{
SUPERPLASTICITY AND SUPERPLASTIC FORMING OF CERAMICS*
}

\author{
T.G. NIEH and J. WADSWORTH
}

Lawrence Livermore National Laboratory, P.O. Box 808, L-350, Livermore, CA 94550, USA

\begin{abstract}
Recent advances in the basic understanding of superplasticity and superplastic forming of ceramics are reviewed. Deformation mechanisms as well as microstructural requirements for superplastic ceramics are discussed. Microstructural effects, such as grain size, dynamic grain growth, and the presence of grain-boundary liquid phases, on the superplastic properties and deformation behavior of ceramics are addressed. Superplastic forming, and particularly biaxial gas-pressure forming, of several ceramics, including YTZP and $\mathrm{Al}_{2} \mathrm{O}_{3} /$ YTZP, is also presented. The forming behavior of these ceramics is correlated with that obtained from conventional uniaxial tests. Examples of concurrent superplastic forming and diffusion bonding (SPF/DB) of metal-ceramic hybrids are given.
\end{abstract}

\section{INTRODUCTION}

Superplasticity is usually defined to be the ability of certain materials to undergo extraordinary tensile deformation [1]. The intense scientific and commercial study of superplasticity began only in about 1960 . As a result of these intensive efforts, superplasticity has been developed in a wide range of metallic materials, including $\mathrm{Ti}, \mathrm{Al}, \mathrm{Fe}$, and $\mathrm{Ni}$ alloys [2], and the structural prerequisites required for superplasticity are reasonably well understood.

Despite the extensive studies of superplastic behavior in metallic systems, work on superplasticity in ceramics and ceramic composites is of very recent origin. This is primarily because ceramics normally fracture intergranularly at low strain values, as a result of a weak grain-boundary cohesive strength. Productive research in superplastic ceramics actively began only in the late 1980s but has expanded very rapidly. The ceramics and ceramic composites made superplastic to date are based on the principles developed for metallic alloys. Existing data indicate that for the case of polycrystalline ceramics, a grain size of less than $1 \mu \mathrm{m}$ is necessary for superplastic behavior. This is in contrast to superplastic metals, in which grain sizes are typically only required to be less than $10 \mu \mathrm{m}$. To highlight the dominant effect of grain size on the deformation behavior of ceramics, Fig. 1 shows the modulus-compensated flow stresses measured from a number of studies on tetragonal zirconias as a function of diffusivity-compensated strain rate [3-7]. It is evident for a given stress that the strain rate increases dramatically as grain size decreases. Figure 1 illustrates the importance of grain boundary sliding mechanisms in the deformation of fine-grained ceramics.

The first observation " fine grain superplasticity in ceramics, in a yttria-stabilized tetragonal zirconia, is generally attributed to Wakai in 1986 [8]. Since 1986, a number of fine-grained polycrystalline ceramics have been demonstrated to be superplastic in tension. A summary of these activities is listed in Table 1. In the following sections, we will divide these superplastic materials into monolithic ceramics and ceramic composites, and will discuss them accordingly.

\section{SUPERPLASTICITY IN MONOLITHIC CERAMICS}

\subsection{Yttria-Stabilized Tetragonal Zirconia Polycrystal}

The first true polycrystalline ceramic demonstrated to be superplastic was $3 \mathrm{~mol} \%$ yttriastabilized tetragonal zirconia polycrystal (YTZP) and this is now considered to be the model

\footnotetext{
* This work was performed under the auspices of the U.S. Department of Energy by LLNL under contract No. W-7405-Eng-48. The financial support was provided by the Army Research Office.
} 
ceramic system. It has been the most widely studied, yet the experimental results are also probably the most controversial. The microstructure of the material, shown in Fig. 2, reveals equilibrated, hexagonal-shaped grains with sharp apexes with a mean grain size of about $0.3 \mu \mathrm{m}$.

Table 1 Property Data of Superplastic Ceramics and Ceramic Composites in Tension.

\begin{tabular}{|c|c|c|c|c|c|}
\hline Material & Microstructure & $\begin{array}{c}\text { Testing } \\
\text { Parameters } \\
\end{array}$ & $\begin{array}{c}\text { Max. } \\
\text { Elong.. \% }\end{array}$ & Material Variables* & Ref. \\
\hline \multicolumn{6}{|l|}{ Monolithics } \\
\hline 3Y-TZP & $\mathrm{d}=0.3 \mu \mathrm{m}$ & & 200 & $\begin{array}{c}\mathrm{n}=2, \mathrm{p}=2 \\
\mathrm{Q}=590 \mathrm{~kJ} / \mathrm{mol}\end{array}$ & {$[8]$} \\
\hline $3 \mathrm{Y}-\mathrm{TZP}$ & $\begin{array}{c}\mathrm{d}=0.30 \mu \mathrm{m} \\
\text { no glassy phase }\end{array}$ & $\begin{array}{c}1550^{\circ} \mathrm{C} \\
8.3 \times 10^{-5} \mathrm{~s}^{-1}\end{array}$ & 800 & $\begin{array}{c}n=1.5, p=3 \\
Q=510 \mathrm{~kJ} / \mathrm{mol}\end{array}$ & [7] \\
\hline 3Y-TZP & $\mathrm{d}=0.3 \mu \mathrm{m}$ & $\begin{array}{c}1450^{\circ} \mathrm{C} \\
4.8 \times 10^{-5} \mathrm{~s}^{-1}\end{array}$ & 246 & $\begin{array}{c}\mathrm{n}=2, \mathrm{p}=\mathrm{NA} \\
\mathrm{Q}=580 \mathrm{~kJ} / \mathrm{mol}\end{array}$ & [9] \\
\hline $\begin{array}{l}\mathrm{Al}_{2} \mathrm{O}_{3}-500 \mathrm{ppm} \\
\mathrm{Y}_{2} \mathrm{O}_{3}\end{array}$ & $\mathrm{~d}=0.66 \mu \mathrm{m}$ & $\begin{aligned} & 1450^{\circ} \mathrm{C} \\
\sim & 10^{-4} \mathrm{~s}^{-1}\end{aligned}$ & $>65$ & $\begin{array}{c}\mathrm{n}=\mathrm{NA}, \mathrm{p} / \mathrm{n}=1.5 \\
\mathrm{Q}=\mathrm{NA}\end{array}$ & [10] \\
\hline Hydroxyapatite & $\mathrm{d}=0.64 \mu \mathrm{m}$ & $\begin{array}{c}1050^{\circ} \mathrm{C} \\
1.4 \times 10^{-4} \mathrm{~s}^{-1}\end{array}$ & $>150$ & $\begin{array}{c}\mathrm{n}>3, \mathrm{p} / \mathrm{n}=1 \\
\mathrm{Q}=\mathrm{NA}\end{array}$ & [11] \\
\hline$\beta$-spodumene glass & $\begin{array}{l}\mathrm{d}=0.91-2.0 \mu \mathrm{m} \\
>4 \text { vol } \% \text { glassy phase }\end{array}$ & $\begin{array}{r}1200^{\circ} \mathrm{C} \\
10^{-4} \mathrm{~s}^{-1} \\
\end{array}$ & $>400$ & $\begin{array}{c}\mathrm{n}=1, \mathrm{p}=3.1 \\
\mathrm{Q}=707 \mathrm{~kJ} / \mathrm{mol}\end{array}$ & [12] \\
\hline \multicolumn{6}{|l|}{ Composites } \\
\hline 20wt $\mathrm{Al}_{2} \mathrm{O}_{3} / \mathrm{YTZP}$ & $\begin{array}{c}\mathrm{d}=0.50 \mu \mathrm{m} \\
\text { no glassy phase }\end{array}$ & $\begin{array}{c}1650^{\circ} \mathrm{C} \\
4 \times 10^{-4} \mathrm{~s}^{-1}\end{array}$ & 620 & $\begin{array}{c}n=2, p=1.5 \\
Q=380 \mathrm{~kJ} / \mathrm{mol}\end{array}$ & [13] \\
\hline 20wt $\mathrm{Al}_{2} \mathrm{O}_{3} / \mathrm{YTZP}$ & $\mathrm{d}=0.50 \mu \mathrm{m}$ & $\begin{array}{l}1450^{\circ} \mathrm{C} \\
10^{-4} \mathrm{~s}^{-1}\end{array}$ & 200 & $\begin{array}{c}n=2, p=N A \\
Q=600 \mathrm{~kJ} / \mathrm{mol}\end{array}$ & [14] \\
\hline $10 \mathrm{vol} \% \mathrm{ZrO}_{2} / \mathrm{Al}_{2} \mathrm{O}_{3}$ & $\mathrm{~d}=0.5 \mu \mathrm{m}$ & $\begin{array}{c}1400^{\circ} \mathrm{C} \\
10^{-4} \mathrm{~s}^{-1}\end{array}$ & $>100$ & $\mathrm{n}=?, \mathrm{p}=?, \mathrm{Q}=?$ & [15] \\
\hline & $\begin{array}{l}\mathrm{d}\left(\mathrm{ZrO}_{2}\right)=0.47 \mu \mathrm{m} \\
\mathrm{d}\left(\mathrm{Al}_{2} \mathrm{O}_{3}\right)=1.0 \mu \mathrm{m}\end{array}$ & $\begin{array}{c}1550^{\circ} \mathrm{C} \\
2.8 \times 10^{-4} \mathrm{~s}^{-1}\end{array}$ & 110 & $\begin{array}{c}\mathrm{n}=2, \mathrm{p}=\mathrm{NA} \\
\mathrm{Q}=700 \mathrm{~kJ} / \mathrm{mol}\end{array}$ & [16] \\
\hline $30 \mathrm{wt} \% \quad \mathrm{TiC} / \mathrm{Al}_{2} \mathrm{O}_{3}$ & $\mathrm{~d}=1.2 \mu \mathrm{m}$ & $\begin{array}{c}1550^{\circ} \mathrm{C} \\
1.2 \times 10^{-4} \mathrm{~s}^{-1}\end{array}$ & 66 & $\begin{array}{c}\mathrm{n}=4, \mathrm{p}=\mathrm{NA} \\
\mathrm{Q}=853 \mathrm{~kJ} / \mathrm{mol}\end{array}$ & [17] \\
\hline$\beta^{\prime}$-SiAION & $\begin{array}{l}\qquad \mathrm{d}=0.4 \mu \mathrm{m} \\
\text { with glassy phase }\end{array}$ & $\begin{array}{l}1550^{\circ} \mathrm{C} \\
10^{-4} \mathrm{~s}^{-1}\end{array}$ & 230 & $\begin{array}{c}\mathrm{n}=1.5, \mathrm{p}=\mathrm{NA}, \\
\mathrm{Q}=\mathrm{NA}\end{array}$ & [18] \\
\hline $15 \mathrm{wt} \mathrm{SiC} / \mathrm{Si}_{3} \mathrm{~N}_{4}$ & $\begin{array}{l}\mathrm{d}=0.2-0.5 \mu \mathrm{m} \\
\text { with glassy phase }\end{array}$ & $\begin{array}{c}1600^{\circ} \mathrm{C} \\
4 \times 10^{-5} \mathrm{~s}^{-1}\end{array}$ & $>150$ & $\begin{array}{c}\mathrm{n}=2, \mathrm{p}=\mathrm{NA} \\
\mathrm{Q}=649-698 \mathrm{~kJ} / \mathrm{mol}\end{array}$ & [19] \\
\hline 20 vol $\mathrm{Fe} / \mathrm{Fe}_{3} \mathrm{C}$ & $\mathrm{d}=3.4 \mu \mathrm{m}$ & $\begin{array}{r}1000^{\circ} \mathrm{C} \\
10^{-4} \mathrm{~s}^{-1} \\
\end{array}$ & 600 & $\begin{array}{c}\mathrm{n}=1.6, \mathrm{p}=2.9 \\
\mathrm{Q}=200-240 \mathrm{~kJ} / \mathrm{mol}\end{array}$ & {$[20]$} \\
\hline
\end{tabular}

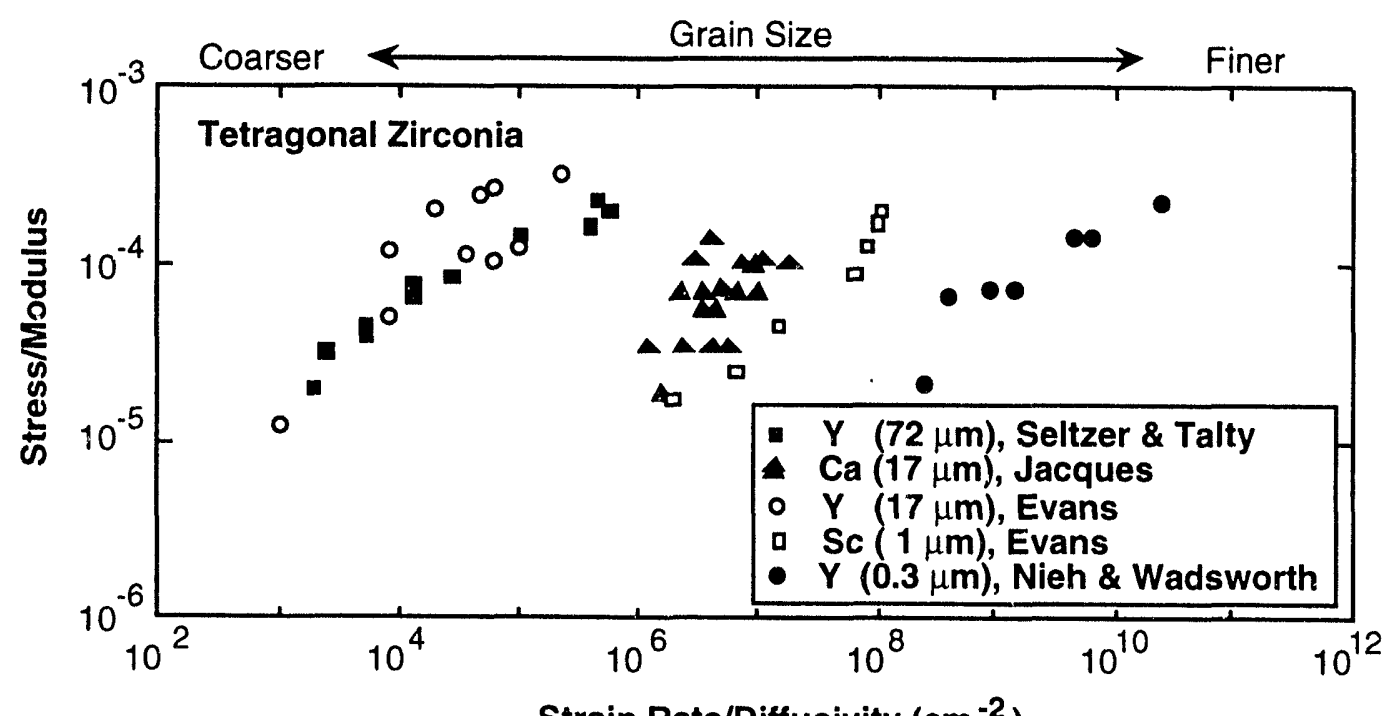

Fig. 1 Modulus-compensated, plastic flow stress as a function of diffusion-compensated, strain rate for tetragonal zirconia. (data from Ref. [3-7]) 


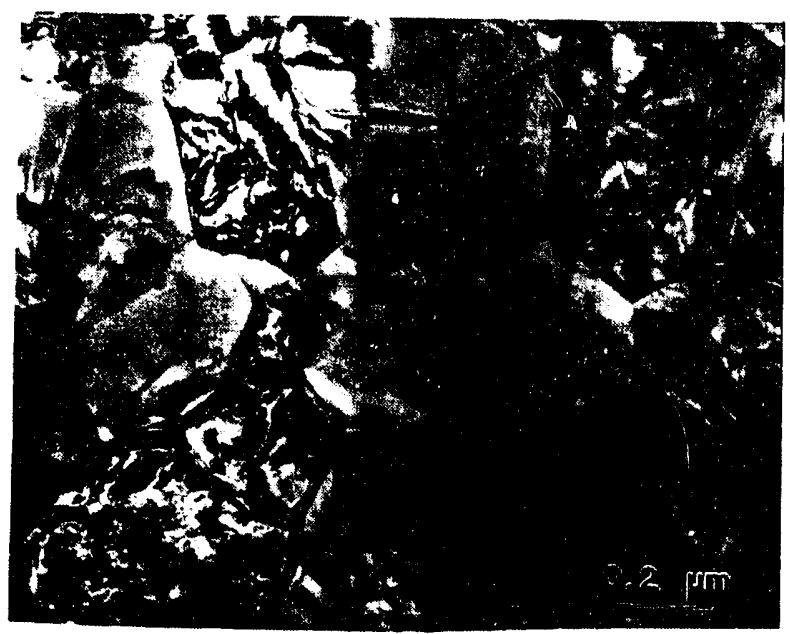

Fig. 2

Transmission electron micrograph of as-received YTZP, showing equilibrated, hexagonalshaped grains.

Tensile elongations were only 5 and $60 \%$ at 1000 and $1200^{\circ} \mathrm{C}$, respectively, but elongations of greater than $100 \%$ were routinely obtained at temperatures above $1350^{\circ} \mathrm{C}$. A maximum value of elongation-to-failure of $800 \%$ has been recorded in a sample tested at $1550^{\circ} \mathrm{C}$ and at a strain rate of $8.3 \times 10^{-5} \mathrm{~s}^{-1}$. A direct comparison of this superplastically-deformed sample with an untested sample is shown in Fig. 3.

There exists a great disparity in the strain rate sensitivity exponent values for YTZP that have been reported in the literature; these vary from 0.3 [21-23] to 0.5 [8, 9, 24-26]. Two major factors - impurity content, and microstructural evolution during deformation, have been suggested to contribute to the different $m$ values that have been measured.

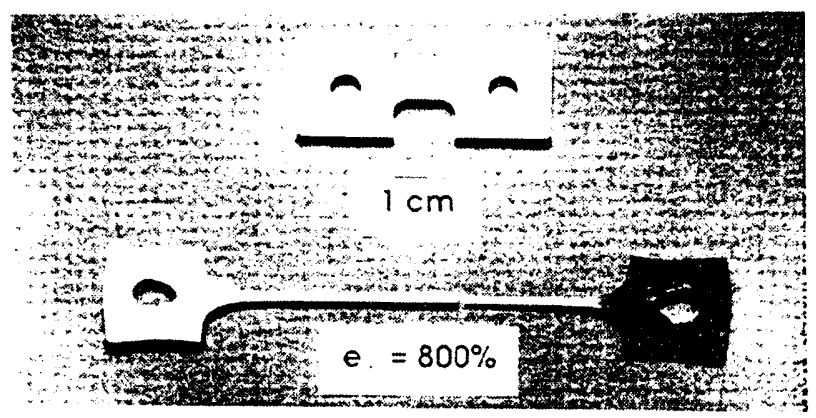

Fig. 3

Comparison of a superplastically deformed YTZP sample (800\%) with an undeformed sample.

A viewpoint has been proposed by $\mathrm{Ma}$ and Langdon [23] who have speculated that the measured strain rate sensitivity value is dependent upon the impurity level in YTZP. They suggest that the higher the impurity content, and thus the higher the glass content at grain boundaries, the higher the strain rate sensitivity value. On the other hand, Nieh and Wadsworth [27] pointed out that microstructural evolution during deformation, and in particular concurrent grain growth, can result in specific artificial effects on the determination of $m$ values. To correct for the effect of concurrent grain growth by normalizing the stress with the square of the final grain size (a grain size dependency of $\sigma \propto d^{2}$ is used [27]), the "true" strain rate sensitivity exponent for YTZP is shown about 0.67; this result is illustrated in Fig. 4 [27].

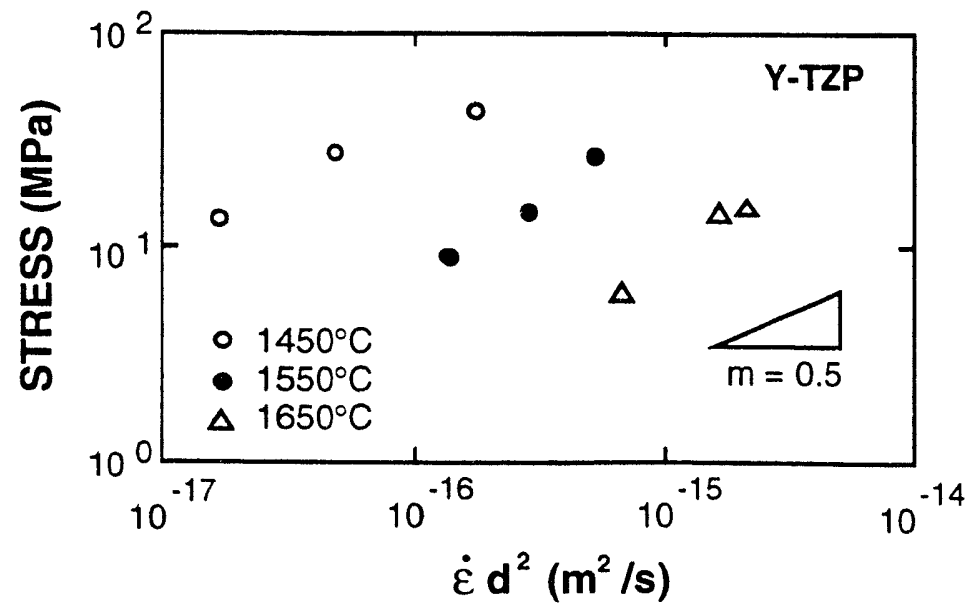

Fig. 4

Flow stress as a function of grain size normalized strain rate. The strain rate sensitivity exponents are less than 0.5 for all temperatures. 


\subsection{Alumina}

Superplasticity is generally difficult to obtain in alumina, as a result of rapid grain growth during high temperature deformation $[28,29]$. Nonetheless, there still exist several studies on superplasticity in doped, fine-grained $\mathrm{Al}_{2} \mathrm{O}_{3}$. These include the studies of Carry and colleagues $[10,22,28,30-32]$ and Yoshizawa and Sakuma [33]. Gruffel et al. [10] demonstrated that the grain size of $\mathrm{Al}_{2} \mathrm{O}_{3}$ can be refined by adding $500 \mathrm{ppm} \mathrm{MgO}$ and $500 \mathrm{ppm} \mathrm{Y}_{2} \mathrm{O}_{3}$. As a result of a fine grain size $(0.66 \mu \mathrm{m})$, the $\mathrm{Al}_{2} \mathrm{O}_{3}$ exhibits a rupture elongation of $65 \%$ at $1450^{\circ} \mathrm{C}$ under an applied stress of $20 \mathrm{MPa}$. Although a tensile elongation of $65 \%$ is not as high as those observed in superplastic metals, it is a large plastic tensile deformation and at least implies the potential for superplasticity in $\mathrm{Al}_{2} \mathrm{O}_{3}$.

\subsection{Hydroxyapatite}

Hydroxyapatite $\left(\mathrm{Ca}_{10}\left(\mathrm{PO}_{4}\right)_{6}(\mathrm{OH})_{2}\right)$ is the human body's own ceramic and a primary constituent in enamel, dentine, and bone tissue. Dense, equiaxed, and fine-grained $(\sim 0.64 \mu \mathrm{m})$ hydroxyapatite can be produced through advanced powder metallurgy processes [34]. The fine-grained material has been demonstrated to be superplastic [11]; the maximum elongation of greater than $150 \%$ was recorded at $1050^{\circ} \mathrm{C}$ at a strain rate of $1.4 \times 10^{-4} \mathrm{~s}^{-1}$. Substantial strain hardening, caused by grain growth during superplastic deformation was observed in the $\sigma-\varepsilon$ curves. The $\mathrm{m}$ value is less than 0.33 which is attribute to rapid grain growth during superplastic testing. Hydroxyapatite was the first functional ceramic shown to be superplastic.

\section{$1.4 \quad \beta$-Spodumene Glass-Ceramics}

Wang and Raj [35] studied the deformation mechanisms of two fine-grained (grain sizes from 0.91 to $2 \mu \mathrm{m}$ ) lithium aluminosilicate $\beta$-spodumene glass-ceramics (containing 4 to $9 \mathrm{vol} \%$ of liquid phase) and observed superplasticity in both materials. Tensile elongations of $135 \%$ and $400 \%$ were recorded from the two materials tested at a strain rate of $10^{-4} \mathrm{~s}^{-1}$ and at temperatures between 1150 and $1200^{\circ} \mathrm{C}$, which are noted to be above the solidus temperatures of the test materials. The results showed that the stress exponent was unity and $\dot{\varepsilon} \propto d^{-3}$, from which it was concluded that the deformation was limited by the diffusion of atoms through the liquid phase, a process which was modeled by Raj [36] and Pharr and Ashby [37].

\section{SUPERPLASTICITY IN CERAMIC COMPOSITES}

\subsection{Zirconia-Based Composites}

Two zirconia-based composite systems have been explored; $\mathrm{Al}_{2} \mathrm{O}_{3}$-reinforced YTZP $\left(\mathrm{Al}_{2} \mathrm{O}_{3} / \mathrm{YTZP}\right)$ and mullite-reinforced YTZP. Alumina-zirconia composite is considered to be an ideal material system because there is no intermediate phase existing between alumina and zirconia. Among the $\mathrm{Al}_{2} \mathrm{O}_{3} / \mathrm{YTZP}$ duplex composites, the $20 \mathrm{wt} \% \mathrm{Al}_{2} \mathrm{O}_{3} / \mathrm{YTZP}$ has been the most extensively studied. The material consists of equiaxed $\mathrm{ZrO}_{2}$ (bright) and $\mathrm{Al}_{2} \mathrm{O}_{3}$ (dark) grains, both are about $0.5 \mu \mathrm{m}$. Wakai and Kato [14] first showed that this material was superplastic and reported an maximum tensile elongation of over $200 \%$. Nieh and Wadsworth [13] further recorded a maximum elongation of $625 \%$, obtained from material tested at $1650^{\circ} \mathrm{C}$ and at a strain rate of $4.0 \times 10^{-4} \mathrm{~s}^{-1}$. The composite generally showed superplastic elongations of over $200 \%$ at temperatures above $1450^{\circ} \mathrm{C}$ at strain rates from $2.7 \times 10^{-5}$ to $1.7 \times 10^{-3} \mathrm{~s}^{-1}$. The strain rate sensitivity value for the composite was about 0.5 and remained constant throughout the temperatures range from 1250 to $1650^{\circ} \mathrm{C}$, suggesting that a single superplastic deformation mechanism, specifically grain boundary sliding, prevails.

In addition to the $20 \mathrm{wt} \% \mathrm{Al}_{2} \mathrm{O}_{3} /$ YTZP, Wakai et al. [16] have systematically studied the superplastic properties of $\mathrm{ZrO}_{2} / \mathrm{Al}_{2} \mathrm{O}_{3}$ duplex composites with various amounts of $\mathrm{Al}_{2} \mathrm{O}_{3}$, ranging from 20 to $80 \mathrm{wt} \%$. Tensile elongation to failure in these composites decreases with increasing $\mathrm{Al}_{2} \mathrm{O}_{3}$ content but is still over $120 \%$ in the $80 \mathrm{wt} \% \mathrm{Al}_{2} \mathrm{O}_{3}$ composite tested at $1550^{\circ} \mathrm{C}$ and a strain rate of $2.8 \times 10^{-4} \mathrm{~s}^{-1}$. Strain rate-stress behavior for these duplex composites is summarized in Fig. 5. The strain rate sensitivity is about 0.5 for all the $\mathrm{ZrO}_{2} / \mathrm{Al}_{2} \mathrm{O}_{3}$ composites. The value was lowest (about 0.4 ) for the 50-50 composite and increased along either side of the equiatomic composition. Assuming alumina is much harder than zirconia, Wakai et al suggested that the superplastic flow behavior of the composite can be qualitatively described by a rheological equation [38]:

$$
\dot{\varepsilon}=(1-V)^{q} \cdot A \cdot \sigma^{n}
$$


where $V$ is the volume fraction of alumina, and $q$ is a constant, depending upon the $n$ value and nature of the second phase.

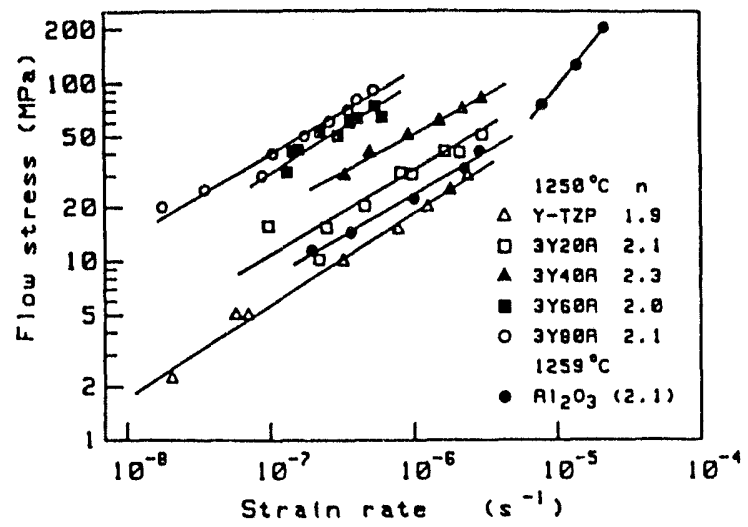

Fig. 5 Flow stress of $\mathrm{Al}_{2} \mathrm{O}_{3} / \mathrm{YTZP}$ composites as a function of strain rate, at $1250^{\circ} \mathrm{C}$. (Data from Ref. [16])

In the case of mullite/zirconia (2YTZP), superplastic flow of the composites with various amounts of mullite, ranging from 10 to 50 vol.\%, has been characterized by Yoon and Chen [39]. In this case, mullite exhibits a fibrous morphology. Yoon and Chen [39] incorporated the morphological feature of the hard phase (mullite) and developed the following equation to express the superplasticity of the composites:

$$
\dot{\varepsilon}=\left(1-V_{\text {mullite }}\right)^{2+n / 2} \cdot A\left(\frac{\sigma^{n}}{d^{3}}\right) \exp \left(-\frac{Q}{R T}\right)
$$

This equation may be generally useful to describe the superplasticity of a composite, provided that the deformation of a monolithic material and its composite can both be described by a similar mathematical form.

\subsection{Silicon Nitride-Based Composites}

Silicon carbide-silicon nitride $\left(\mathrm{SiC}_{\mathrm{Si}} \mathrm{N}_{4}\right)$ composite is an attractive structural ceramic because of its high-temperature strength and oxidation resistance. Wakai and co-workers [19, 40-42] demonstrated that a fine-grained $\mathrm{SiC} / \mathrm{Si}_{3} \mathrm{~N}_{4}$ composite can be synthesized and behaves superplastically. The composite was prepared initially from an amorphous Si-C-N powder which was produced by vapor phase reaction of $\left[\mathrm{Si}\left(\mathrm{CH}_{3}\right)_{3}\right]_{2} \mathrm{NH} / \mathrm{NH}_{3} / \mathrm{N}_{2}$ at $1000^{\circ} \mathrm{C}[43,44]$. Bulk materials were produced by mixing the amorphous powder with $6 \mathrm{wt} \% \mathrm{Y}_{2} \mathrm{O}_{3}$ and $2 \mathrm{wt} \% \mathrm{Al}_{2} \mathrm{O}_{3}$ as sintering aids, and further hot pressing at $1650^{\circ} \mathrm{C}$ and $34 \mathrm{MPa}$ in $\mathrm{N}_{2}$. The above processes resulted in a composite with approximately $20-30 \mathrm{wt} \% \mathrm{SiC}$. The microstructure of the composite consisted of both spherical grains $(<0.2 \mu \mathrm{m})$ and elongated grains $(<0.5 \mu \mathrm{m})$. The material exhibited a superplastic elongation of over $150 \%$ at $1600^{\circ} \mathrm{C}$ at an initial strain rate of $4 \times 10^{-5} \mathrm{~s}^{-1}$. As a result of the reactions amongst $\mathrm{Y}_{2} \mathrm{O}_{3}, \mathrm{Al}_{2} \mathrm{O}_{3}$, and $\mathrm{Si}_{3} \mathrm{~N}_{4}$ at the superplastic temperature, $1600^{\circ} \mathrm{C}$, a substantial amount of intergranular liquid phase was present in the composite.

\subsection{Iron Carbide-Based Composites}

Kim et al. $[20,45]$ have demonstrated superplasticity in a fine-grained iron-iron carbide $(\mathrm{Fe} / \mathrm{Fe} 3 \mathrm{C})$ composite with a $6.25 \% \mathrm{C}-1.5 \% \mathrm{Cr}$ hypereutectic iron composition. The microstructure consists of 80 vol.\% of fine equiaxed grains $(\sim 4 \mu \mathrm{m})$ of $\mathrm{Fe}_{3} \mathrm{C}$ and 20 vol\% of iron-based second phase. The material is superplastic at temperatures between 700 and $1000^{\circ} \mathrm{C}$ with low values of stress exponent $(n=2$ to 1$)$ and tensile elongations as high as $600 \%$. The strain rate in the $n=2$ region is inversely proportional to approximately the cube of the grain size with an activation energy for superplastic flow of between 200 and $240 \mathrm{~kJ} / \mathrm{mol}$. Superplastic flow in the iron carbide material, in the $n=2$ region, was proposed to be governed by grain-boundary sliding accommodated by slip, i.e., controlled by the diffusion of iron along iron carbide grain boundaries. 
In an attempt to understand the parameters controlling the optimum superplastic elongation, in this $\mathrm{Fe} / \mathrm{Fe}_{3} \mathrm{C}$ composite as well as YTZP, $\mathrm{Al}_{2} \mathrm{O}_{3} / \mathrm{YTZP}$, and $\mathrm{Al}_{2} \mathrm{O}_{3}$, $\mathrm{Kim}$ et al. [46] have correlated the maximum tensile elongation as a function of temperature-compensated strain rate, i.e. $\dot{\varepsilon} \cdot \exp (Q / R T)$, for a number of superplastic ceramics; this result is given in Fig. 6 . Assuming that the plastic flow of superplastic ceramics can be described by the Dorn equation, Fig. 6 essentially indicates that tensile elongation is determined by flow stress. A similar conclusion has also been proposed by Chen and Xue [47].

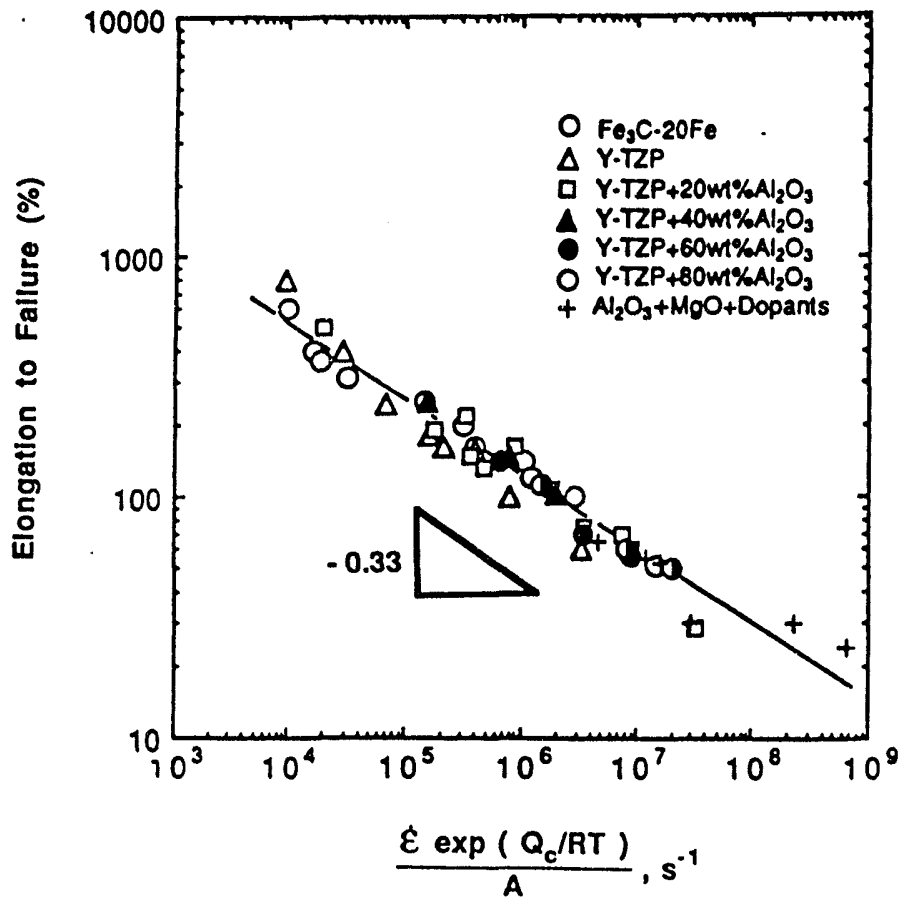

Fig. 6

Elongation to failure plotted as a function of normalized strain rate for various superplastic ceramics and ceramic composites. (from Ref. [46])

\section{GRAIN BOUNDARIES IN SUPERPLASTIC CERAMICS}

A general question concerning the microstructure of superplastic ceramics is: "Is the presence of a grain-boundary glassy phase necessary in order to produce superplasticity?" The answer is important to the design and processing of ceramic materials. Microstructural studies on grain boundaries have mainly been carried out in YTZP. The findings are however quite controversial. For example, Nieh et al. [48] have presented several pieces of experimental evidence to show that there is no grain boundary glassy phase in their superplastic YTZP and $20 \mathrm{wt} \% \mathrm{Al}_{2} \mathrm{O}_{3} /$ YTZP samples. These experimental results show that lattice fringes from adjoining grains can be followed to their intersections at both the grain boundary interface and the triple junction, indicating the absence of any secund phase. In addition, both Auger Electron Spectroscopy (AES) and X-ray photoelectron Spectroscopy (XPS) from the intergranular fracture surfaces of superplastically deformed specimens show the absence of low melting point glassy phases in YTZP and $20 \mathrm{wt} \% \mathrm{Al}_{2} \mathrm{O}_{3} / \mathrm{YTZP}$ [48]. These results suggest that the presence of a grain boundary glassy phase is unnecessary for superplasticity in fine-grained ceramics. Conversely, the existence of glassy phases at grain boundaries in superplastic YTZP has been reported; Duclos et al. [25] claimed the presence of a glassy phase at triple points in YTZP.

Although the presence of a liquid phase at grain boundaries may not be a necessary prerequisite for superplasticity in ceramics, its presence can definitely affect grain boundary sliding [37, 49]. For example, Wakai et al. [50] have demonstrated that the temperature for superplasticity in YTZP can be reduced by doping manganese oxidu $(\sim 3 \mathrm{~mol} \%)$ into the material to create a grain-boundary glassy phase. Also, Hwang and Chen [51] and Xur [52] found that a minor addition $(0.3 \mathrm{~mol} \%)$ of $\mathrm{CuO}$ to YTZP can reduce the sintering temperature without significantly inçreasing the grain size. The CuO-doped YTZP can be formed superplastically at $1150^{\circ} \mathrm{C}$. 


\section{SUPERPLASTIC FORMING AND DIFFUSION BONDING}

\subsection{Closed Die Forming}

Several parts have been successfully formed superplastically from fine-grained YTZP. For example, Kellett et al. [53] demonstrated that submicron-sized $(\sim 0.23 \mu \mathrm{m})$ YTZP powders can be extruded superplastically, with an 8 to 1 reduction in area ratio (or a true strain of -2.2 ), at $1500^{\circ} \mathrm{C}$ to near full density. Panda et al. [54] and Yamana et al. [55] have applied a sinterforging technique to form bulk $\mathrm{ZrO}_{2}$ stabilized by various amount of $\mathrm{Y}_{2} \mathrm{O}_{3}$ from fine powders to full density at $1400^{\circ} \mathrm{C}$. Wakai et al. [56] successfully formed a 3 YTZP sheet sample at $1450^{\circ} \mathrm{C}$. Recently, Wu and Chen [57] demonstrated that a 2 YTZP containing $0.3 \mathrm{~mol} \% \mathrm{CuO}$ can be superplastically formed into hemispheric dome shapes at $1150^{\circ} \mathrm{C}$.

\subsection{Gas Pressure Forming}

Wittenauer et al. [58] have performed gas pressure biaxial forming of superplastic YTZP sheet. Experiments were conducted over a temperature range of $1450^{\circ}$ to $1600^{\circ} \mathrm{C}$ and forming pressures in the range of 345 to $2760 \mathrm{kPa}$. The forming behavior for YTZP sheet at a pressure of $690 \mathrm{kPa}$ at various temperatures is summarized in Fig. 7. For the forming conditions employed, a nominal flow stress was selected for each of the forming pressures. This corresponds to the "steady-state" deformation (region 2) observed in the deformation-time plots presented in Fig. 7. In this manner, the forming stress-strain rate data are presented in Fig. 8. The data indicate that the average strain rate $\dot{\varepsilon}$, is proportional to the nominal flow stress raised to the $n$th power, i.e.:

$$
\dot{\varepsilon}=B \cdot \sigma^{n}
$$

The data of Fig. 8 exhibit a stress exponent $n$ of 2 for the tests conducted at high applied pressure with $n$ increasing to a value of 3 at lower applied stresses. This result is in agreement with results obtained from uniaxial tension tests. An increasing stress exponent in the low stress region has been observed previously in uniaxial tension of superplastic YTZP and was attributed to dynamic grain growth [7].
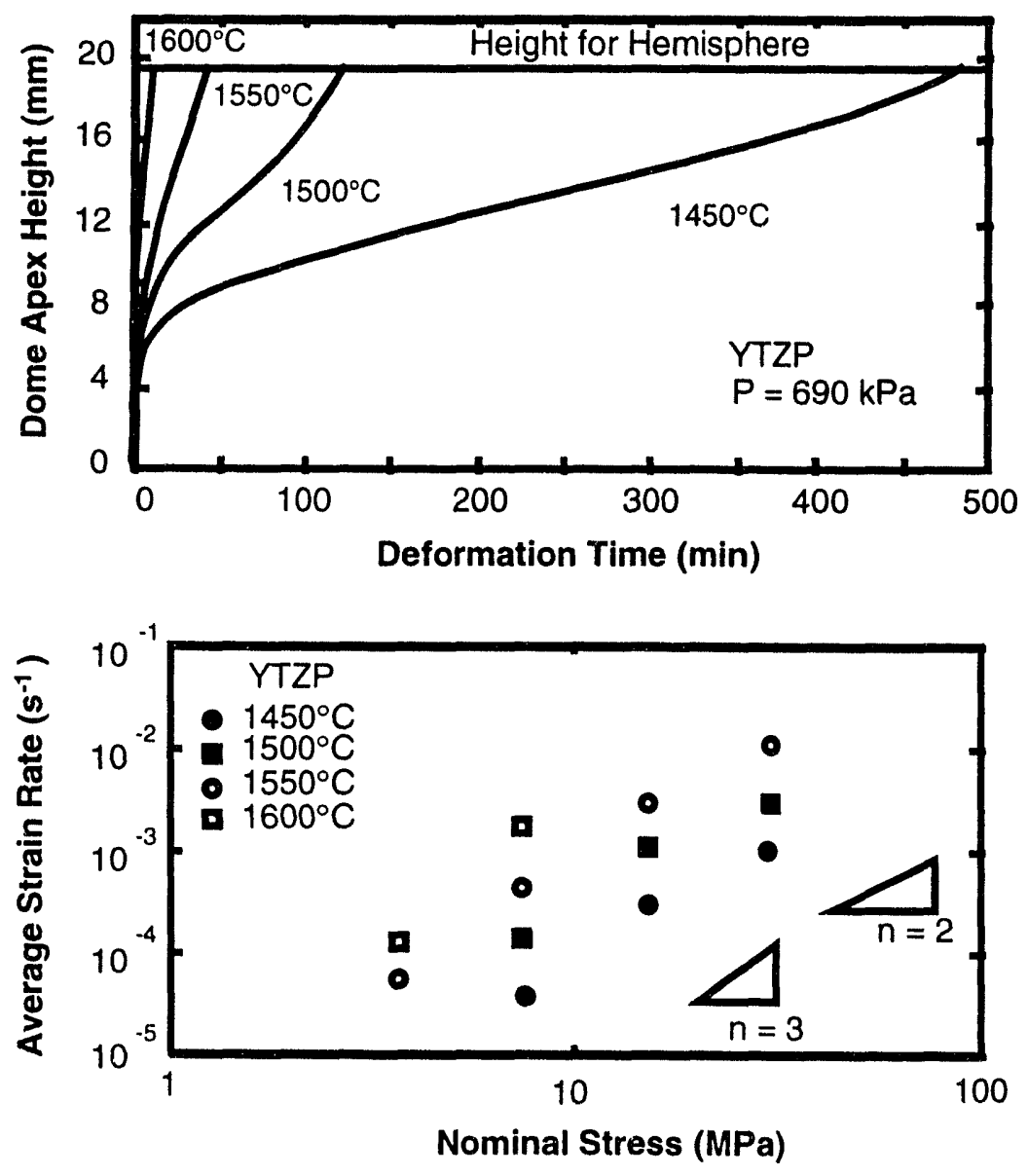

Fig. 7

Deformation-time curves for superplastic gas-pressure forming of YTZP.
Fig. 8

Average strain rate versus nominal stress. Data indicate the stress exponent at low strain rates is about 3 . 
A direct comparison is shown in Fig. 9 between the strain rate-stress data obtained from the biaxial forming experiments and those from uniaxial tests [7]. It is evident in Fig. 9 that, despite the fact that the strain rate from the biaxial forming test is generally faster than that from the uniaxial tests, both sets of data indicate a slightly decreasing stress exponent in the high strain rate region. The higher strain rate for the biaxial forming tests, versus the uniaxial tests, is believed to be caused primarily by uncertainty in the calculation of the nominal stress acting in the shell [58]. The uncertainty arises from the simplification of a nonuniform shell thickness during deformation. As, a result of non-uniform thinning, the measured thickness at the apex of the formed hemispheres is much less than that predicted when a uniform thickness distribution is assumed. In addition to YTZP, $20 \% \mathrm{Al}_{2} \mathrm{O}_{3} / \mathrm{YTZP}$ hemispheres were made at temperatures between 1450 and $1600^{\circ} \mathrm{C}$, and at forming pressures of 345 and $690 \mathrm{kPa}$. The biaxial forming behavior for $\mathrm{Al}_{2} \mathrm{O}_{2} / \mathrm{YTZP}$ sheet is virtually similar to that for YTZP. Also, the uniaxial deformation of $20 \% \mathrm{Al}_{2} \mathrm{O}_{3} / \mathrm{YTZP}$ is similar to biaxial deformation.

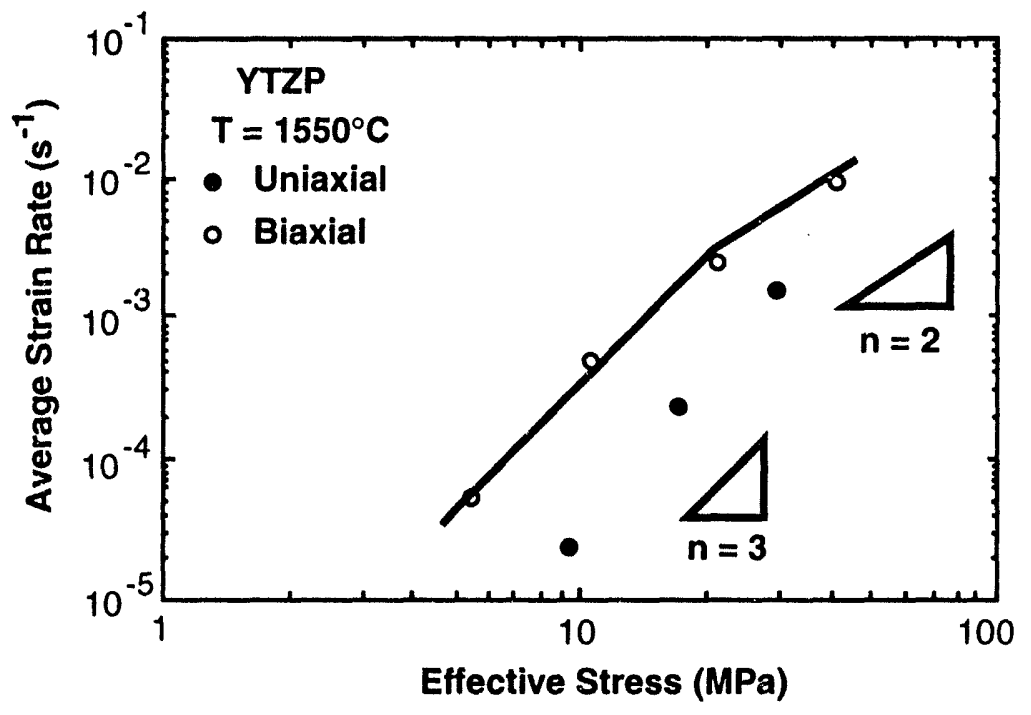

Fig. 9

A direct comparison between data from biaxia and uniaxial tests of YTZP.

\subsection{Hybrid YTZP/C103 (SPF/DB)}

A combination of superplastic deformation with diffusion bonding offers the opportunity to manufacture a range of useful engineering structures. For example, ceramics can be bonded to metals during superplastic deformation to yield either a ceramic-metal laminate or to add selective metallization for attachment of fasteners. As an example of the potential for manufacturing metal-ceramic hybrids, the concurrent diffusion bonding and co-deformation of a YTZP ceramic disc and the $\mathrm{Nb}$-based refractory alloy $\mathrm{C}-103$ (composition: $\mathrm{Nb}-10 \mathrm{Hf}-1 \mathrm{Ti}$ ) has been evaluated [59]. Discs of YTZP and C-103 were assembled into the biaxial gas-pressure deformation apparatus and co-deformed at a temperature of $1500^{\circ} \mathrm{C}$. Hemispherical sections with the $\mathrm{Nb}$-based alloy integrally bonded to the underlying YTZP were successfully made. Thus, the possibility to utilize superplastic deformation and simultaneous diffusion bonding creates the potential for the fabrication of truly unique engineering structures.

\section{SUMMARY}

In the past decade, ceramic superplasticity has rapidly advanced from a period of fundamental laboratory study to a level at which ceramic articles may be formed superplastically by gas pressure deformation. The next step in this evolutionary process is the actual manufacture of net-shaped articles. Using the technology developed for the present study, it is now possible to make intricately shaped, net shaped parts from superplastic ceramic sheet. Examples of such articles, a cone-on-cylinder geometry, a hat section, and a hemisphere are shown in Fig. 10. The articles were all formed within a forming time of $20-90$ minutes (depending upon the strain required) at a forming pressure of $690 \mathrm{kPa}$ and a temperature of $1550^{\circ} \mathrm{C}$. A multitude of shape geometries are possible with this process - as determined by the shape of the die. Continued studies are needed to understand more fully the relationships 
between deformation variables (pressure, temperature) and deformation behavior (forming rate, strain distribution, cavitation).

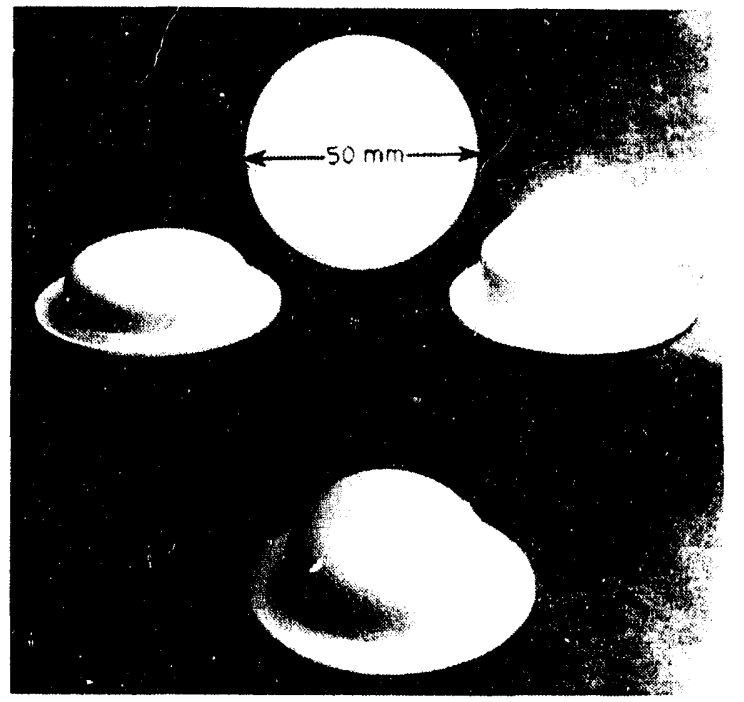

Fig. 10

Net-shaped articles superplastically formed from YTZP sheet are limited only by the die design.

\section{REFERENCES}

1. O.D. Sherby and J. Wadsworth, Deformation, Processing and Structure (edited by G. Krauss), p. 355, ASM, Metal Park, Ohio (1984).

2. N.E. Paton and C.H. Hamilton, ed. Superplastic Forming of Structural Alloys. The Metallurgical Society of AIME, Warrendale, Pennsylvania (1982).

3. R.G. St-Jacques and R. Angers, J. Am. Ceram. Soc. 55571 (1972).

4. P.E. Evans, J. Am. Ceram. Soc. 53365 (1970).

5. R.G. St-Jacques and R. Angers, Trans. Br. Ceram. Soc. 72285 (1972).

6. M.S. Seltzer and P.K. Talty, J. Amer. Ceram. Soc. 58124 (1975).

7. T.G. Nieh and J. Wadsworth, Acta Metall. Mater. 381121 (1990).

8. F. Wakai, S. Sakaguchi, and Y. Matsuno, Adv. Ceram. Mater. 1259 (1986).

9. T. Hermanson, K.P.D. Lagerlof, and G.L. Dunlop, Superplasticity and Superplastic Forming (edited by C.H. Hamilton and N.E. Paton), p. 631, TMS (1988).

10. P. Gruffel, P. Carry, and A. Mocellin, Science of Ceramics, Volume 14 (edited by D. Taylor), p. 587, The Institute of Ceramics, Shelton, Stoke-on-Trent, UK (1987).

11. F. Wakai, Y. Kodama, S. Sakaguchi, and T. Nonami, J. Am. Ceram. Soc 73257 (1990).

12. J.-G. Wang and R. Raj, J. Am. Ceram. Soc. 67,(6) 399 (1984).

13. T.G. Nieh and J. Wadsworth, Acta Metall. Mater. 39.037 (1991).

14. F. Wakai and H. Kato, Adv. Ceram. Mater. 3,(1) 71 (1988).

15. L.A. Xue, X. Wu, and I.W. Chen, J. Am. Ceram. Soc. 74,(4) 842 (1991).

16. F. Wakai, Y. Kodama, S. Sakaguchi, N. Murayama, H. Kato, and T. Nagano, MRS Intl. Meeting on Advanced Materials Vol 7 (IMAM-7, Superplasticity) (edited by M. Doyama, S. Somiya, and R.P.H. Chang), p. 259, Materials Research Soc., Pittsburgh, Pennsylvania (1989).

17. T. Nagano, H. Kato, and F. Wakai, J. Am. Ceram. Soc. 742258 (1991).

18. X. Wu and I.-W. Chen, J. Am. Ceram. Soc. 75,(10) 2733 (1992).

19. F. Wakai, Y. Kodama, S. Sakaguchi, N. Murayama, K. Izaki, and K. Niihara, Nature (London) 334,(3) 421 (1990).

20. W.J. Kim, G. Frommeyer, O.A. Ruano, J.B. Wolfenstine, and O.D. Sherby, Scr. Metall. 231515 (1989)

21. T.G. Nieh, C.M. McNally, and J. Wadsworth, Scr. Metall. 221297 (1988).

22. C. Carry, MRS Intl. Meeting on Advanced Materials Vol.7 (IMAM-7, Superplasticity) (edited by M. Doyama, S. Somiya, and R.P.H. Chang), p. 251, Materials Research Soc., Pittsburgh, PA (1989).

23. Y. Ma and T.G. Langdon, Superplasticity in Metals, Ceramics, and Intermetallics, MRS Proceeding No. 196 (edited by M.J. Mayo, J. Wadsworth, and M. Kobayashi), p. 325, Materials Research Society, Pittsburgh, PA (1990).

24. F. Wakai, S. Sakaguchi, and H. Kato, J. Ceram. Soc. Japan 9472 (1986). 
25. R. Duclos, J. Crampon, and B. Amana, Acta Metall. 70877 (1987).

26. Y. Okamoto, J. Ieuji, Y. Yamada, K. Hayashi, and T. Nishikawa, Advances in Ceramics, Vol. 24 (edited by S. Somiya, N Yamamoto, and H. Yanagida), p. 5Ć5, American Ceramic Society, Westerville, Ohio (1988).

27. T.G. Nieh and J. Wadsworth, Scr. Metall. Mater. 24763 (1990).

28. J.D. Fridez, C. Carry, and A. Mocellin, Structure and Properties of $\mathrm{MgO}$ and $\mathrm{Al}_{2} \mathrm{O}_{3}$ Ceramics (edited by W.D. Kingery), p. 720, American Ceramic Society, Columbus, Ohio (1984).

29. L.A. Xue and I.W. Chen, J. Am. Ceram. Soc. 73,(11) 3518 (1990).

30. C. Carry and A. Mocellin, Proc. Brit. Ceram. Soc 33101 (1983).

31. C. Carry, Superplasticity in Metals, Ceramics, and Intermetallics, MRS Proceeding No.196 (edited by M.J. Mayo, J. Wadsworth, and M. Kobayashi), p. 313, Materials Research Society, Pittsburgh, PA (1990).

32. C. Carry and A. Mocellin, High Tech Ceramics (edited by P. Vincenzini), p. 1043, Elsevier Science Publishers, Amsterdam (1987).

33. Y. Yoshizaka and T. Sakuma, Acta Metall. Mater. 402943 (1992).

34. M. Jarco, C.H. Bolen, M.B. Thomas, J. Bobick, J.F. Kay, and R.H. Doremus, J. Mater. Sci. 112027 (1976).

35. J.-G. Wang and R. Raj, J. Am. Ceram. Soc. 67,(6) 385 (1984).

36. R. Raj, J. Geophys. Res. 87,(B6) 4731 (1982).

37. G.M. Pharr and M.F. Ashby, Acta Metall. 31129 (1983).

38. I.W. Chen, in Superplasticity, ed. B. Baudelet and M. Suery. Centre National de la Recherche Scinetifique, Paris, France (1985). p. 5.

39. C.K. Yoon and I.W. Chen, J. Amer. Ceram. Soc 73,(6) 1555 (1990;,

40. F. Wakai, Superplasticity in Metals, Ceramics, and Intermetallics, MkS Proceeding No. $196 R$ (edited by M.J. Mayo, J. Wadsworth, and M. Kobayashi), p. 349, Materials Research Society, Pittsburgh, PA (1990).

41. T. Rouxel, F. Wakai, K. Izaki, and K. Niihara, Pro. 1st Inter. Symp. on Science of Engineering Ceramics (edited by S. Kimura and K. Niihara), p. 437, Ceramic Society of Japan, Tokyo. Japan (1991).

42. T. Rouxel, F. Wakai, and K. Izaki, J. Am. Ceram. Soc. 752363 (1992).

43. K. Izaki, K. Hakkei, K. Ando, and K. Niihara, Ultrastructure Processing of Advanced Ceramics (edited by J.D. Mackenzie and D.R. Ulrich), p. 891, John Wiley \& Sons, New York (1989).

44. K. Niihara, K. Suganuma, A. Nakahira, and K. Izaki, J. Mater. Sci. Lett. 9598 (1990).

45. W.J. Kim, J. Wolfenstine, O.S. Ruano, G. Frommeyer, and O.D. Sherby, Metall. Trans. 23A 527 (1992).

46. W.J. Kim, J. Wolfenstine, and O.D. Sherby, Acta Metall. Mater. 39199 (1991).

47. I.-W. Chen and L.A. Xue, J. Am. Ceram. Soc. 732585 (1990).

48. T.G. Nieh, D.L. Yaney, and J. Wadsworth, Scripta Metall. 232007 (1989).

49. M. Gust, G. Goo, J. Wolfenstine, and M. Mecartney, J. Am. Ceram. Soc. 761681 (1993).

50. F. Wakai, H. Okamura, N. Kimura, and P.G.E. Descamps, Proc. 1st Japan Int'l SAMPE Symp. (edited by N. Igata, K. Kimpara, T. Kishi, E. Nakata, A. Okura, and T. Uryu), p. 267, Society for the Advancement of Materials and Process Engineering (1989).

51. C.-M.J. Hwang and I.W. Chen, J. Amer. Ceram. Soc. 731623 (1990).

52. L.A. Xue, J. Mater. Sci. Lett. 101291 (1991).

53. B.J. Kellett, C. Carry, and A. Mocellin, Superplasticity and Superplastic Forming (edited by C.H. Hamilton and N.E. Paton), p. 625, The Minerals, Metals, and Materials Society, Warrendale, PA (1988).

54. P.C. Panda, J. Wang, and R. Raj, J. Amer. Ceram. Soc. 71 C-507 (1988).

55. Y. Yamana, Y. Y., S. Nakamura, K. Kitagawa, T. Yoshimura, T. Mano, and Y. Shintani, J. Ceram. Soc. Japan 97758 (1989).

56. F. Wakai, Brit. Ceram. Trans. J. 88205 (1989).

57. X. Wu and I.W. Chen, J. Am. Ceram. Soc. 73,(3) 746 (1990).

58. J.P. Wittenauer, T.G. Nieh, and J. Wadsworth, J. Am. Ceram. Soc. 761665 (1993).

59. J.P. Wittenauer, T.G. Nieh, and J. Wadsworth, Processing and Fabrication of Advanced Materials (edited by J.J. Morris), p. 541, TMS, Warrendale, PA (1992). 

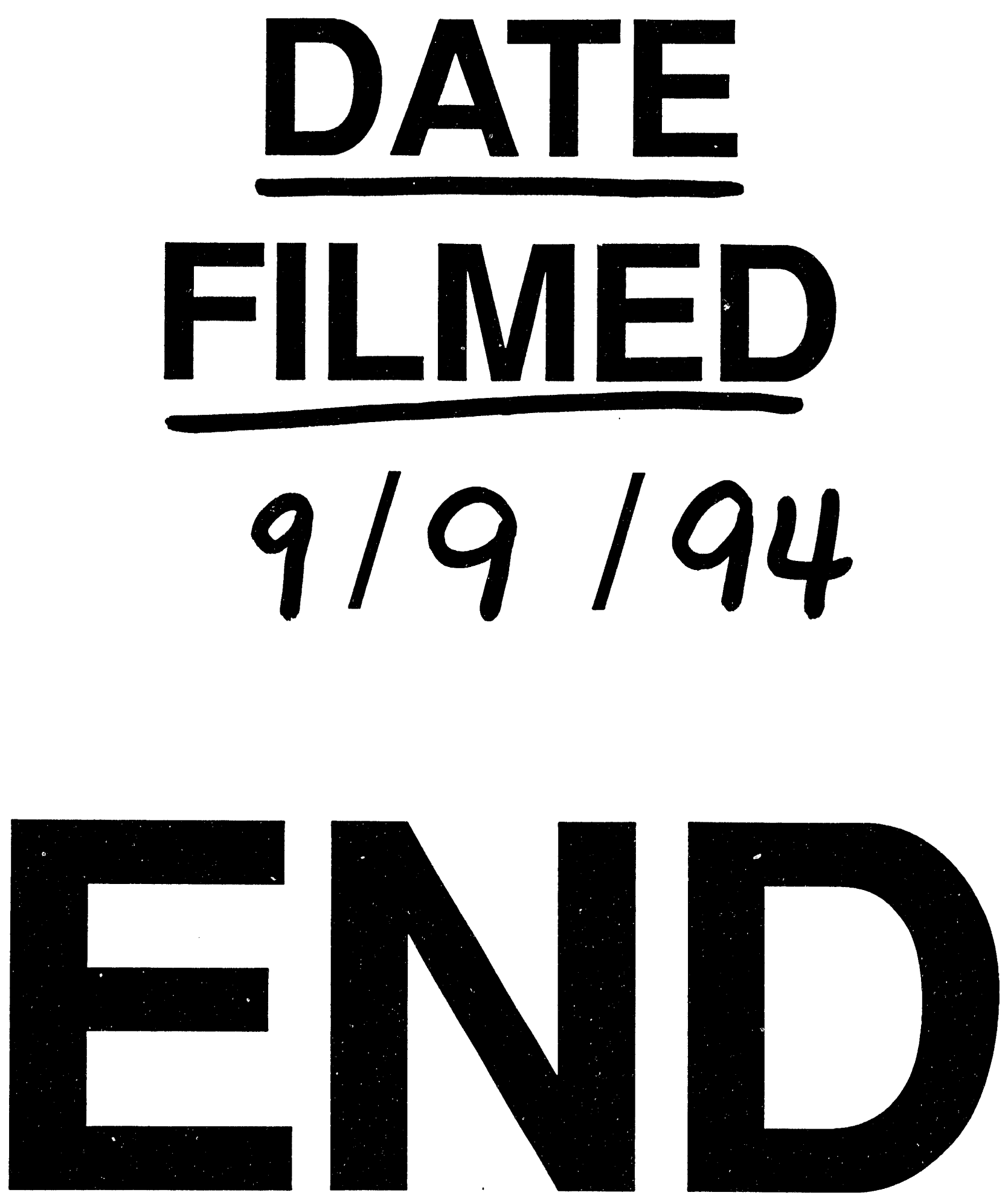
